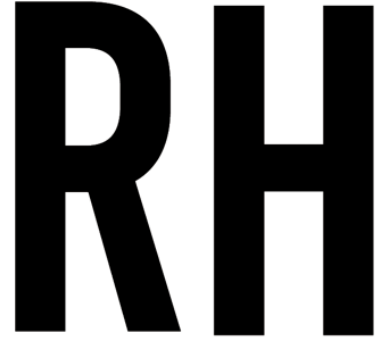

RADICALHOUSINGJOURNAL

\title{
Occupy, resist,
} construct, dwell! A genealogy of urban occupation movements in central São Paulo

\author{
Jeroen Stevens \\ OSA Research Group on Urbanism \& Architecture \\ University of Leuven, Belgium
}

Jeroen Stevens is an architect and urbanist, engaged as a post-doctoral researcher at the OSA Research Group on Urbanism \& Architecture at the University of Leuven (Belgium). His work focusses on the particular interplay between

urbanism and urban movements, exploring the methodological nexus

of urban analysis and urban anthropology. He closely

collaborates therefor with social movements, cultural collectives,

human rights associations and governmental as well as academic institutions. Contact:

jeroen.stevens@kuleuven.be

\begin{abstract}
This paper offers a genealogy of building occupations carried out by occupation movements in central São Paulo to shed light on the particular form of urbanism that emanates from such downtown occupation practices. The main objective is to illustrate how occupation movements played a structural role in the urban recuperation of São Paulo's central area by re-inhabiting a disaggregated stockpile of vacant buildings with thousands of homeless families, initiating parallel processes of architectural renewal and social reform. To that end, the contribution reconstructs the emergence and subsequent proliferation of occupation movements in central São Paulo between the 1970s and the 2010s. It dwells on particular exemplary building occupations during this period. This contribution draws from extensive discourse analysis, and multiple years of participant observation carried out in close collaboration with multiple occupations movements, especially the FLM (Alliance of the Struggle for Housing) and the MSTC (Homeless Movement of the Centre).
\end{abstract}

\section{Keywords}

inclusive urbanism, mutual aid, squatting, urban activism, urban social movements

\section{Introduction}

Between the 1970s and the present, numerous organized urban social movements have been engaged in organized struggles for housing across almost all major Latin American cities (See, e.g.: Gilbert, 1994). This is certainly the case in Brazil, where large-scale squatter 
settlements rapidly urbanized the peripheral areas of large cities, many of which were led by organized movements (Holston, 2008; Maricato, 2011). Since the late 1990s, and in São Paulo in particular, organized housing movements began squatting in the city's downtown area. While the (since then evicted) 'Torre David' in Caracas undoubtedly became one of the worlds' most famed squatted 'vertical communities' (Brillembourg \& Klumpner, 2012), São Paulo's central districts came to accumulate over a hundred temporary organized building occupations during the latest two decades. This article seeks to shed light on the particular genealogy of occupations and occupation movements that came to percolate the inner city of São Paulo. It is based on extensive discourse analyses, especially of movement pamphlets and major newspapers. This work stems from a larger research project on occupation movements in São Paulo, drawing from multiple years of participant observation and urban analysis. Around two years of fieldwork were spend living in different occupations of the MSTC (Homeless Movement of the Centre) and the FLM (Alliance of the Struggle for Housing) between 2014 and 2019.

The article is largely structured in three parts. The first section commences with the occupation of the Mooca Cinema in 1977. It sketches out the formation process of innercity occupation movements in São Paulo between the 1970s and the 1990s. The second part begins with the occupation of the Santos Dumont mansion in 1997. It elaborates upon the proliferation of occupations and occupation movements during the 1990s and the 2000s. The third section singles out the particular contemporary occupation of the INSS building, re-occupied by the MSTC in 2017. This section illustrates the particular urban life that plays out in downtown occupied buildings. Finally, some concluding remarks draw attention to the structural presence of such building occupations in the central city, and the nascent 'right to the centre' that emanates from this peculiar downtown housing typology that is in formation. A parallel photo-essay highlights particular spaces and practices at play in the currently occupied INSS building. It seeks to convey a closer look into the distinct spatiality and sociability of the occupations of MSTC and FLM. All photographs are made by the author between 2017 and 2019.

\section{The Cinema de Mooca Occupation: Harbinger of Reclaim}

In 1977, after being evicted from a nearby cortiç - a particular type of downtown tenement housing - a loosely organised group of tenants occupied an old cinema in São Paulo's downtown industrial neighbourhood of Mooca. ${ }^{1}$ The squatted cinema was soon named one of the city's largest inner-city squats. It was a harbinger of numerous organised building occupations that would emerge 20 years later. The group of squatters was supported by the Housing Pastoral, one of the first institutions to openly protest against the deplorable dwelling conditions found in countless inner-city corticos, where tenants were paying exorbitant rents for insalubrious rooms of merely a few square meters. By the beginning of

\footnotetext{
${ }^{1}$ See Kohara (2013) and Stevens, De Meulder \& Sanches (2019) for more elaborated accounts on the particular cortiço building typology and its important role in the prehistory of organized social housing movements in São Paulo.
} 
the 20th Century, cortiços absorbed the poorest third of the city's population (Kowarick \& Ant, 1989). The city's earliest industrial districts such as Mooca, Bixiga, Bom Retiro, Barra Funda and Brás aggregated downtown tenements, which brought a diverse nomenclature in their wake. Popular depictions came to include cortiços (beehives), quintais (backyards), casas de cômodos (boarding houses), pensões (pensions), hoteis (hotels), casarãos (mansions), and cabeçasde-porco (pork heads), to name a few.

Until the 1970s, cortiços were the city's predominant low-income housing typology. But during the military ruling (1964-1985), the city changed quickly. Investments in industry and infrastructure sparked massive rural-urban migration, from Brazil's impoverished NorthEast regions in particular (Santos, 1996). The military government's National Housing Bank $(\mathrm{BNH})$ rehoused about 4.5 million low-income families in peripheral state-sponsored housing complexes. It was nevertheless unable to cope with the immense urban population boom. Arriving migrants and squeezed-out urbanites alike could no longer be absorbed by the city's cortiços, and by 1980, 8.5 million squatters had erected a small thousand favelas around the consolidated city (Pasternack Tascher, 1995). A plethora of social movements sprung up, many led by women campaigning for improved housing and urban services such as childcare, healthcare, transport and sanitation (Arantes, 2013). From the alleged 'margins' of the city, 'those "without" - without homes, without land, without work, without rights' (Zibechi, 2012, p. 61) leapt to the centre of the urban stage. Housing movements suddenly became new protagonists in the city's territorial and political arena (Sader, 2001).

Also Liberation theology played an important role during the organization of urban social movements in São Paulo. In 'Christian Base Communities' or 'CEBs,' liberation theologists incited the poor to autonomously overcome injustice. Insubordinate direct action was lauded as the celestial path to liberation. 'Liber-a(c)tion' proposed the 'wretched of the earth' (Fanon, 1961) to 'discover the causes of their oppression [and] organize themselves into movements' (Boff \& Boff, 1986, pp. 4-5). Both in the central cortiços and in the peripheral squatter settlements, CEB's were organizing poor communities into political movements by setting up local committees, neighbourhood associations, and base groups (Burdick, 1992).

During this time, Paulo Freire's 'pedagogy of the oppressed' sketched-out educational guidelines closely related to liberation theology. Freire advocated that only 'unity and organization' could allow the poor to 'change their weakness into a transforming force with which they can re-create the world, making it more human' (Freire, 1968, p. 114). In keeping with Freire, efflorescing movements took up the 'great humanistic and historical task of the oppressed ... to liberate themselves and their oppressors ... who exploit, and rape by virtue of their power' (Freire, 1968, p. 21). In the centre of São Paulo, the precarious living conditions found in cortiços heavily provoked the organization of movements, in which tenants and homeless were familiarized with Freire's mantra holding that 'freedom is acquired by conquest, not by gift' (1968, p. 24). In urban social movements, the poor were organizing themselves to claim their rights to the city and dignified citizenship. 
The occupied Mooca Cinema became one of the centre's most important housing base groups. Seven years after the building's occupation, pamphlets announced: 'The union of tenants of Mooca has been born! We don't have anywhere to live, what could we then offer our children? If we eat, we cannot dwell, and if we dwell, we cannot eat! We discovered that decent housing is a basic right for all, but for the workers this clearly doesn't apply. Those that work the most, that wake up the earliest, and sleep the latest, have no place to live! Therefore, we will fight together for decent housing. ${ }^{2}$ Eventually the cortico-movement rebaptised itself as the Movimento dos Quintais da Mooca to avoid the pejorative connotation associated with the term cortiço. The group met weekly at the head office of Mooca's workers' association. In 1984, they presented at the town hall a list of vacant sites in the districts of Mooca and Brás, supposedly appropriate for the construction of low-income housing. They also demanded financial support for the purchase of construction materials (Neuhold, 2016). It was the heydays of mutirão, an indigenous Tupi-Guarani term commonly used by social movements in Brazil to refer to mutual aid practices, especially related to collective cleaning, working and building. In the 1980s, mutirão emerged as a dominant mode of social housing, drawing from the collective self-construction of social movements, public subsidies, and the technical aid of specialized architecture cooperatives called assessorias tècnicas. The first collective self-construction experiments in the Eastern city demonstrated viable scenarios for autonomously rebuilding so-called 'slums' into self-build and self-managed housing projects. With the emergence of mutirão's subsidized collective housing practices, housing movements increasingly took up a fight over autonomy, no longer restricting claims to isolated struggles over water, electricity, and access to land, but simultaneously claiming control over the construction and management of housing solutions. The interlocked fights over space (occupy!) and over its autonomous development (mutirão!) called upon a Lefebvrian right to collectively take part in the making and remaking of the city (Lefebvre, 1968). Space in the city was to be conquered by squatting, and to be made inhabitable through practices of communal mutual aid taking the form of age-old mutirã.

In May 1985, after a year without response, the União dos Moradores de Quintais mobilised 40 members. The Folba de São Paulo (7/5/1985) headlined: 'Cortiço-dwellers invade Mooca's Fabes!' The group occupied the regional office of the Secretary of Family and Well-Being. They departed five days later after the government promised 200 building lots, which was later watered down to 96 mutirão units in the Eastern city-outskirts of Sapopemba, Guaianases and Cidade Tiradentes. The modest conquest gave nonetheless a powerful impetus to the young housing movement. It provided living proof that popular struggle could lead to factual housing solutions. Be that as it may, many former cortiçoinhabitants found out fairly quick that the centre was critical for their subsistence. Many participants were street sweepers and hawkers, nannies and dog walkers, security guards, taxi drivers, cashiers, and the like. They depended on proximity to the centre to make a living. Many sold off their hard-earned housing units and moved back into one or another downtown cortiço. The central movement's luta (literally: fight) increasingly shifted from a struggle for 'housing' to a struggle for 'dignified housing,' which was understood as sound

2 Bolletim, União dos Moradores dos Quintais da Mooca, April 1984. 
apartments in the well-serviced centre, amidst social and cultural amenities, public transport, and low-skilled job opportunities. From then on, the Movimento dos Quintais consciously framed the centre as the pragmatic and symbolic site and subject of its struggle for housing. What had started as a struggle for rights to the city increasingly turned into a struggle for rights to the centre of the city.

Over the course of the 1980s, manifold local base groups and dweller associations merged into larger, professionalized and highly networked housing movements. A first national gathering was held while increasingly large demonstrations brought thousands of favelados (as inhabitants of low-income settlements became popularly named) to the centre for claiming drinkable water, electricity, sewers, and land titles (Levy, 2005). In 1987, the Union of Housing Movements (UMM) united different housing movements to strengthen their weight on the municipal, regional, and federal authorities (Earle, 2017). The UMM undertook successive 'housing caravans' to Brasilia, mobilizing busloads with up to 3,000 movement members to the capital to claim federal investments for low-income housing. Meanwhile, popular mobilization was upscaling and professionalizing across Latin America (Escobar \& Alvarez, 1992). The UMM negotiated for the construction of many thousand low-income housing units, giving voice to hundreds of local housing movements. The union adapted 'a dual strategy of collaboration and contestation' (Earle, 2009, p. 141), continuously alternating between insubordinate direct action and political counselling.

The union was there at the outset of the 1988 constitution, claiming backing for civil organisations. The constitution endorsed principles of democratic urban management, providing legal and political instruments to widen direct participation. It led to the approval of the 2001 'City Statute,' explicitly recognising the 'Social Function of Property' by providing legislative and fiscal instruments that allow municipal administrations to reverse segregated urban development patterns (Fernandes, 2011). Eventually the statute's minimal execution and futile impact provoked movements to insurgently seize 'un-proper' properties and induce their social function from the bottom up through occupation practices.

By the early 1990s, in the midst of exacerbating unemployment and massive social mobilizations, the city's Secretary of Housing and Urban Development (Sehab) was occupied monthly, and often weekly, by members of housing movements. Demands were made for more public measures for housing the poor by means of occupation practices (Maricato, 2011). Occupations hence became a highly-valued social movement tactic to stake out territorial and political claims. Within unfinished social housing projects, empty lands, governmental headquarters, and central avenues, squatters became omnipresent in the urban physiognomy of central São Paulo.

On 15 June 1991, in a cortiço in the Carmo Street, multiple cortico-associations gathered and set up the Unificação das Lutas dos Cortiços (ULC), the first downtown movement that integrated different popular quarters from the centre in a unified cortiço-movement. They explicitly claimed popular housing for the lowest income workers in the very centre of the city (Neuhold, 2016). From its inception onwards, the movement focused on the centre's paradoxical congregation of appalling homelessness amidst an abundance of vacant buildings. 
Given the mounting economic and political crisis that afflicted the city in the early 1990s, in 1992 the ULC initiated Apoio, the Association of Mutual Support of the Eastern Region (literally also translating as 'support'). Apoio's initial work concentrated on fighting hunger and illiteracy among the city's most vulnerable population. They closely worked together with the Catholic Pastorals. Firmly bound-up with Apoio, the ULC came of age, uniting manifold cortico associations from all over the centre. Nonetheless, the movement's enlargement went hand in hand with exacerbating internal contention. Right away, diverging political affiliations, disagreement over operational methods, and discordant ideological stances divided the movement's leading figures. While consolidating Apoio, the group concurrently broke away from the ULC and set up the Fórum dos Corticos de Sem-Teto (Forum of Homeless' Tenements). Not much later also the MMC or Housing Movement of the Centre split off from the ULC. The amount of occupations and occupation movements grew in tandem.

The newly established Fórum dos Cortiços and Apoio were closely intertwined. While the former was primarily devoted to political mobilization and direct action, the latter dedicated to immediate social assistance, employment, education, and more 'formal' cooperation with governmental institutions and international funding programs. Incoming budgets were partially channelled to the housing movement, for instance by employing movement coordinators, allowing them to fully dedicate themselves to the movement. The alliance between the 'radical' Fórum and the more 'prudent' Apoio allowed the group to get less beset by widespread debacles over 'revolutionism' as opposed to 'reformism', an ideological conflict that was meanwhile dividing housing movements all over Latin America. With a rudimentary division of labour, the two groups worked hand in hand, broadening the scope of their tactical repertory. As a result, they organized at least eighteen cortiço-groups spread over the central area of São Paulo by 1996.

A decade after the erection of the UMM, years of arduous political negotiations, countless unfulfilled promises, unexecuted projects, hardly enforced legal instruments, and internal disagreements drove the downtown movements to the brink of outrage. On top of the halted mutirão projects, repressive police interventions and numerous evictions afflicted the centre. Escalating unemployment, reaching up to 19.5 per cent by 1999 , and plunging wages made the minor tangible achievements pale, and provoked more direct forms of action. The years following the occupation of the Mooca Cinema in 1977 had given birth to numerous well-organized housing movements. Occupation tactics played already a fundamental role in their activist agendas. The deep political and economic crisis in which they found themselves by the closing of the millennium forced these movements to deploy occupation practices not only as a political means of demonstration, but also as a direct means of autonomous self-housing. The emergence of such occupations will be the focus of the following section. 


\section{The Santos Dumont Occupation: Occupied Centre}

On 8 March 1997, the Forum dos Cortiços de Sem-Teto and Apoio, with around 500 members, occupied the 19th Century coffee-baron's palace known as the Casarão Santos Dumont, located in São Paulo's downtown neighborhood of Campos Elíseos. After the mansion had been expropriated for housing the Fazenda Pública Estadual, it passed through the state's administration of the Secretary of Children, Family and Well-Being. Left unused for multiple years it became informally filled-in as a cortiço. According to the Folba de São Paulo (20 December 1999), many of the occupants had been living here beforehand, paying rent for small rooms. The occupants managed to remain inside for three months while negotiating with the state government to refurbish the building into proper popular housing. The perceived instant success of the occupation instigated a wave of organized occupations in the centre during the months and years to come.

The ULC and the UMM began to occupy abandoned buildings the same year. Key leaders were closely connected to the rural Landless Movement (MST), transposing their tactical land occupations to the centre's urban environment. On 2 April 1997, 100 dwellers were evicted from a cortiço in the neighbourhood of Liberade. Left without other dwelling options, they occupied with the Fórum a set of houses owned by the University of São Paulo, at the corner of Pirineus Street and the Brigadeiro Galvão Street. In the same year, they squatted the INSS building at the Nove de Julho Avenue, one of the numerous properties of the National Institute of Social Security. The occupation mobilized over 1,000 movement members. Meanwhile, governmental institutions prepared more drastic measures for impeding the purportedly disruptive 'invasions.' Two occupations carried out by the Fórum resulted in violent confrontations with military police. In the centre's housing struggle, a new phase was initiated, and vacancy, accumulated over years of mistreatment, became the stage of a new radical performance.

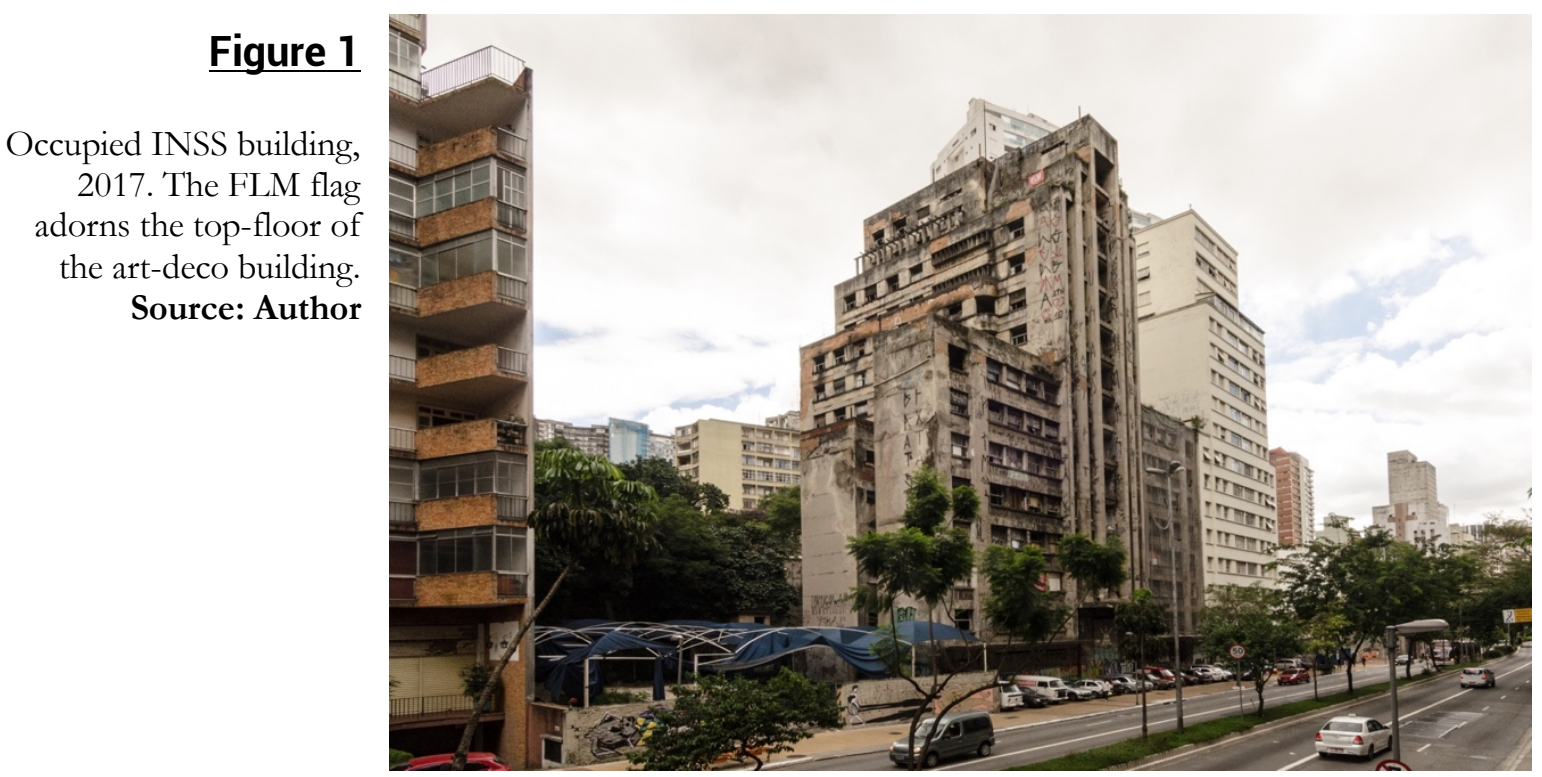


On 5 October 1998, the Fórum occupied the old Matarazzo Hospital in São Paulo’s central neighbourhood of Bixiga to accommodate 300 evicted families. The MMC squatted, amongst others, the 'Ouvidor 63' building, the former Municipal Department of Culture that faced the centre's main bus terminal Bandeiras. As many other movements, also the Fórum was afflicted by internal discontent, and its offspring Movement of the Homeless Workers of the Central Region (MTSTRC) went its own way. Still in 1998, the MTSTRC occupied with more as 350 families a 15 floor residential tower around the corner of the Ouvidor 63 building. New movements arose while other ones disintegrated. Abandoned buildings were squatted all over the centre. The same year, Apoio published an anthology with photographer Wagner Celestino, poignantly titled 'Inner-city tenements: a reality that nobody notices.' The photographic testimony was a 'Call for action: An invitation for getting out of the inertia with concrete activities and actions.' The church, NGO's, civil society and public authorities were asked to make life more just for the peoples of the cortiços (Apoio \& Celestino, 1998, p. 5). The introduction of the photobook was bitter: 'Where can a family go that is under attack of unemployment and salaries offensive to human dignity?' (Apoio \& Celestino, 1998, p. 8). Homeless poor, organized in movements, increasingly recognized occupations as a viable alternative to the plain street, the remote periphery or the exploitative cortiço.

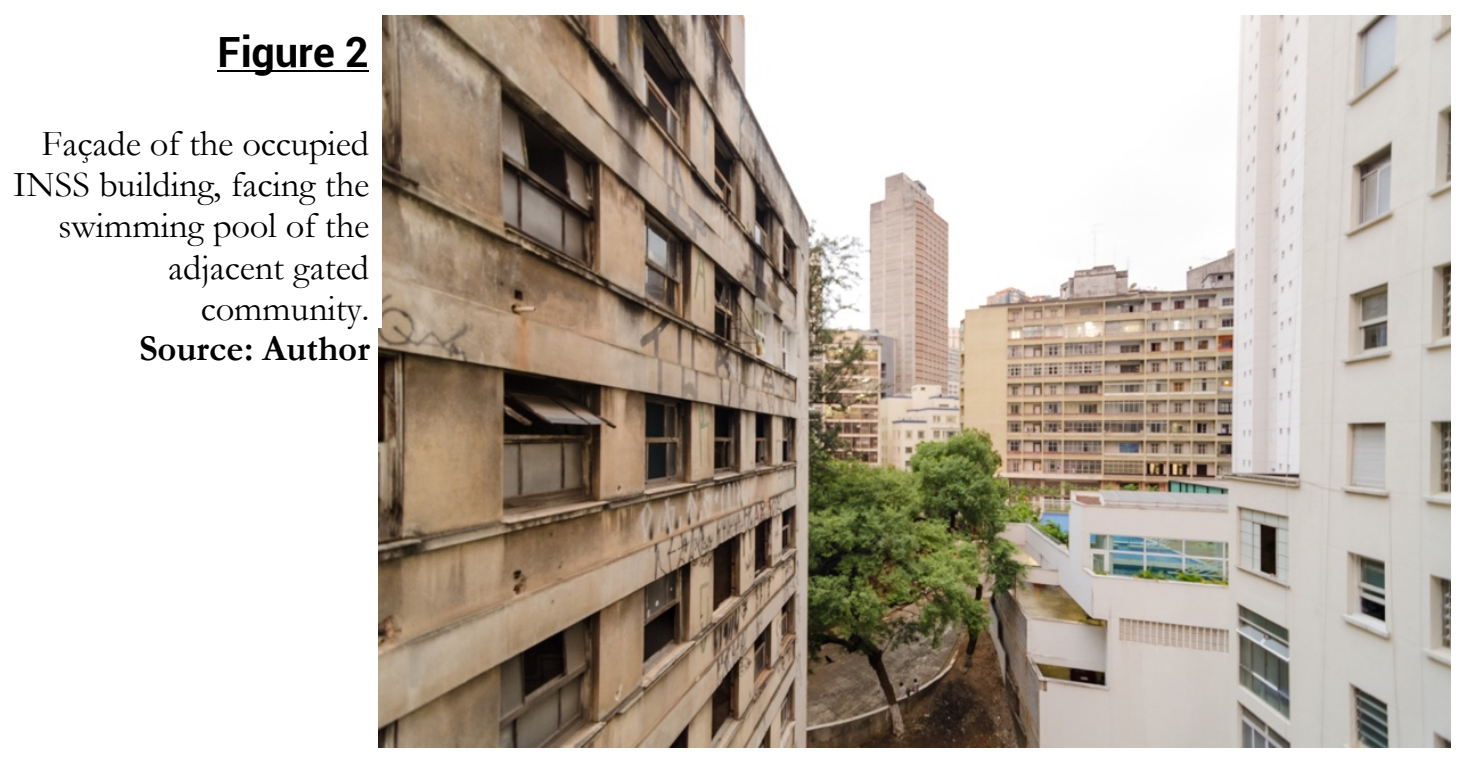

As the $20^{\text {th }}$ Century drew to a close, occupations were omnipresent in the building fabric of downtown São Paulo, emerging as a structural housing type. The municipal secretary of housing estimated that 23,000 persons were inhabiting occupied buildings in the centre, and at least seventeen buildings were occupied by organized squatter movements. ${ }^{3}$ The Fórum trumpeted: 'Don't remain isolated. Enter the fight for your rights! Free yourself from paying rent and join our fight for housing! Central São Paulo is devoid of inhabitants and full of

${ }^{3}$ Folha de São Paulo, (20 December 1999) 9 
vacant edifices. We must unite all the poor and occupy these vacant buildings!"4 And so they did. On 25 October 1999, at midnight, it was proclaimed: '6100 Homeless invade six buildings in less than an hour in São Paulo!' 5 The downtown occupation movements orchestrated an unforeseen prodigious mega-occupation in the centre. Supported by the Housing Pastoral, the UMM conjoined the inner-city Fórum, Apoio, and the Unificação das Lutas dos Corticos (ULC) with the peripheral Movimento Sem Terra Leste 1 and Movimento dos Trabalhadores Sem Terra da Zone Oeste to synchronously seize five public and one private buildings, one of which belonged to the Tribunal Regional do Trabalho (TRT). Also seized was an unfinished project from the state's social housing company. Ironically, the occupation of the social housing project, intended to eventually house homeless families, was the only one that was instantaneously evicted manu militari. Given the massive scale and high visibility of the operation, the city's downtown occupation movements became front page news overnight.

\section{Figure 3}

Occupation of the INSS building in 2017.

Source: Author

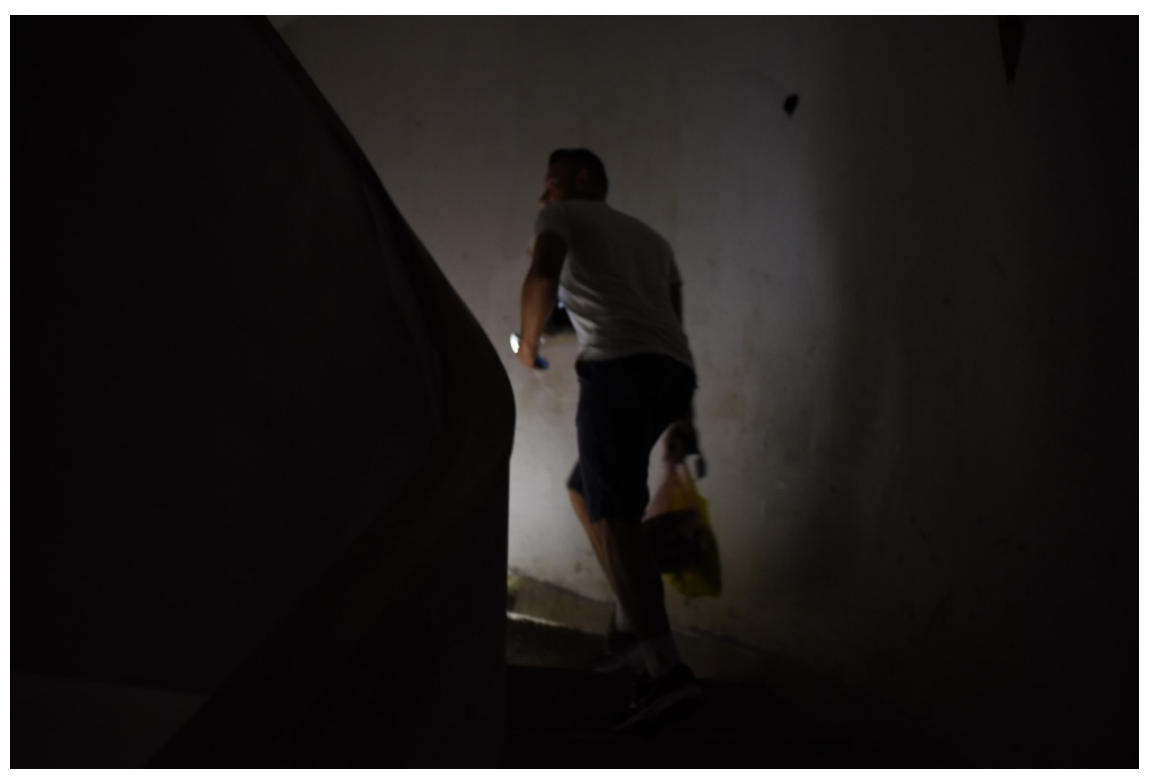

Contention increased after the centre's Security Council (Conseg) signed a pact with authorities to prevent further 'unlawful invasion of the centre." The retrofitting of the aforementioned Santos Dumont occupation into popular housing got blocked by the state's heritage department, and in 2005, it would eventually be transformed in the city's museum of energy, in keeping with the 'cultural' revitalisation that sought to 'revive' the centre (José, 2007). The vice-president of the regional social housing institute admitted that the centre could easily accommodate another 800,000 inhabitants. Public authorities however accused occupation movements of queue-jumping official waiting lists. For Apoio, however, 'The right to housing has no queue!' (Del Rio, 2016, pp. 144-145). As Apoio noted in a 1999 educational text: 'The urban workers create and maintain all that makes the city. Nevertheless, all what they create in the city only serves the rich... The urban land and built

\footnotetext{
${ }^{4}$ Fórum dos Cortiços, Caminho Da Luta, nr. 7, May 1999

${ }^{5}$ Folha de São Paulo, (26 October 1999)

${ }^{6}$ At the time, TRT was involved in a corruption scandal.

7 Folha de São Paulo, (20 December 1999)
} 
fabric serve a horde of parasite owners and speculators. The homeless urban workers work for those rich, they give everything, but are nonetheless left without anything, living in misery.' Occupations were bound to challenge this deeply entrenched social inequality.

Occupying had of course been part and parcel of São Paulo's urban development for centuries. Occupation of land in fact constituted the basis of ownership rights ever since the first colonial land-regulations were established (Rolnik, 1997). The moment that downtown movements took off occupying vacant buildings, movements expanded a diversified tactical repertoire of ongoing squatting practices, integrating it into a cautiously organised civic movement. They seized some of the most valuable properties in the most exposed, bestserviced area of the metropolis. Consequently, they gained prime political importance in the blink of an eye. They were highly symbolic, making strong claims on the centre of the city instead of on one or another peripheral stretch of undervalued territory. Simultaneously, they were highly practical, rehousing the urban poor close to all the central amenities and services in buildings that merely had to be patched up and maintained rather than having to build them from scratch, such as the case in peripheral self-help communities. Central occupations were, after all, repairing and recycling abandoned fragments of the old city rather than adding new additions to its ever-further radiating urban sprawl.

\section{Figure 4}

Installation of electricity network in the newly-occupied

INSS building. Source: Author

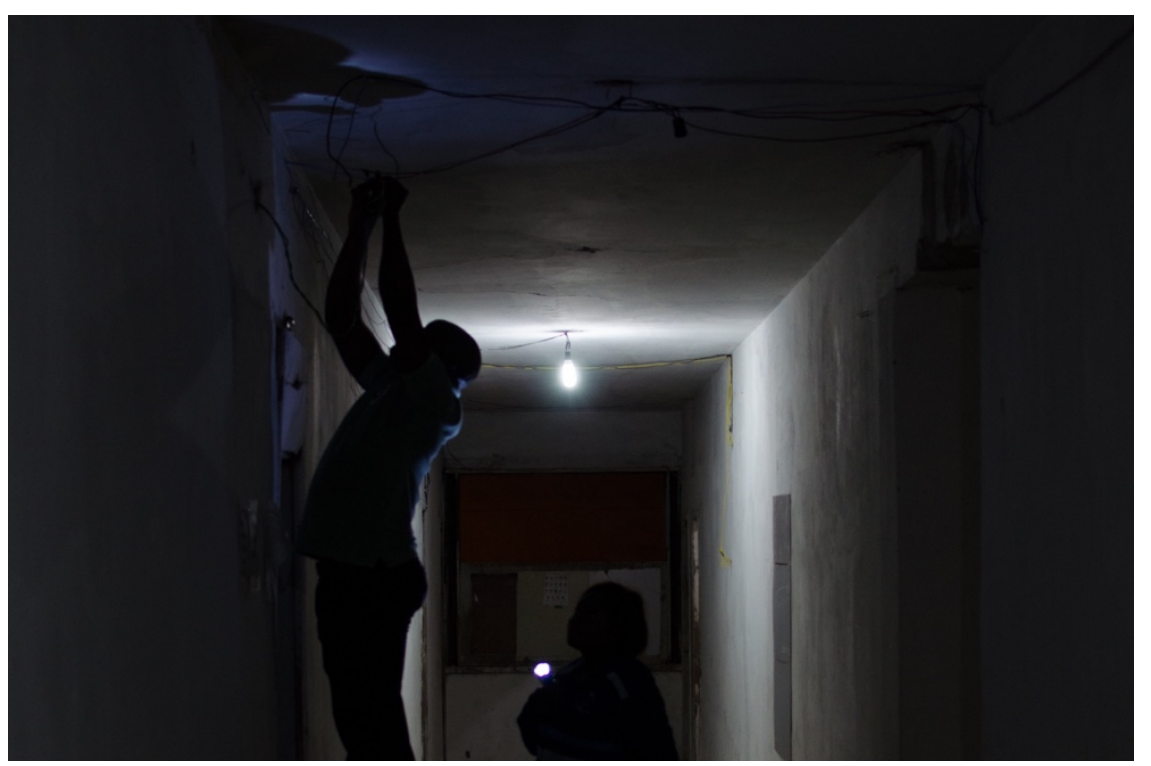

While São Paulo's central movements gained force and visibility throughout the 2000s, internal debate over occupation tactics increased. Multiple movement members questioned the occupations' performativity as viable housing solutions. Occupations were accused of reproducing the cortiços' precarious dwelling conditions which they supposedly sought to overcome in the first place. Similar to the cortiços, most occupations were re-inhabiting residual and partly derelict buildings. The occupied structures were often overcrowded, and contained significant issues related to insalubriousness, over-used sanitation, clandestine electricity and water connections, deficient technical infrastructure, questionable privacy, and ample safety issues. Despite the occupants' liberation from rent, tenure was still insecure, as evictions were commonplace. Discontent strongly invigorated after a fatal accident in 1999, 
when a child fell in the water tank of the occupied Hotel São Paulo (Neuhold, 2016). In 2003, the sixth floor of the occupied industrial Prestes Maia building caught fire, demolishing four entire floors, and taking the life of a four-year-old girl. For sceptics, cortiços or ocupaçoes, tenements or squats, were equally regarded as inner-city 'slums,' and many considered it contradictory to fudge together precarious and hazardous dwellings in crumbling edifices, while purportedly struggling for dignified housing. Thus, the ULC and UMM eventually substituted long-term squatting with symbolic short-term occupation actions aimed at pressurizing governmental housing programs.

Most of Apoio's members, instead, maintained a commitment to autonomous direct action, and split off from the Fórum dos Cortiços. After a year of reorganizing the cortiçomovements, Apoio's new squatting movement entered the stage. The Estadão (5 November 2000) newspaper headlined: 'Violence: About 100 homeless families invade a private building in São Paulo!' The newly baptised Movimento Sem-Teto do Centro (MSTC) rented eight busses to squat an eleven-floor building at 401 Duque de Caxias Avenue. Large banners announced the new movement's major slogan: 'Occupy, Resist, Construct, Dwell!' It drew attention to the movement's intention to autonomously inhabit and refurbish occupations. They were evicted from the building on 24 November 2000, after a violent raid by the military special forces. Five movement members were imprisoned for resisting. Ciléia de Carvalho, coordinator of the occupation, responded: 'If this is how police is treating us, and government does not take measures, what rests us but organizing ourselves and strengthen our occupations?" Over the following years, MSTC indeed became the most forceful occupation movement of downtown São Paulo.

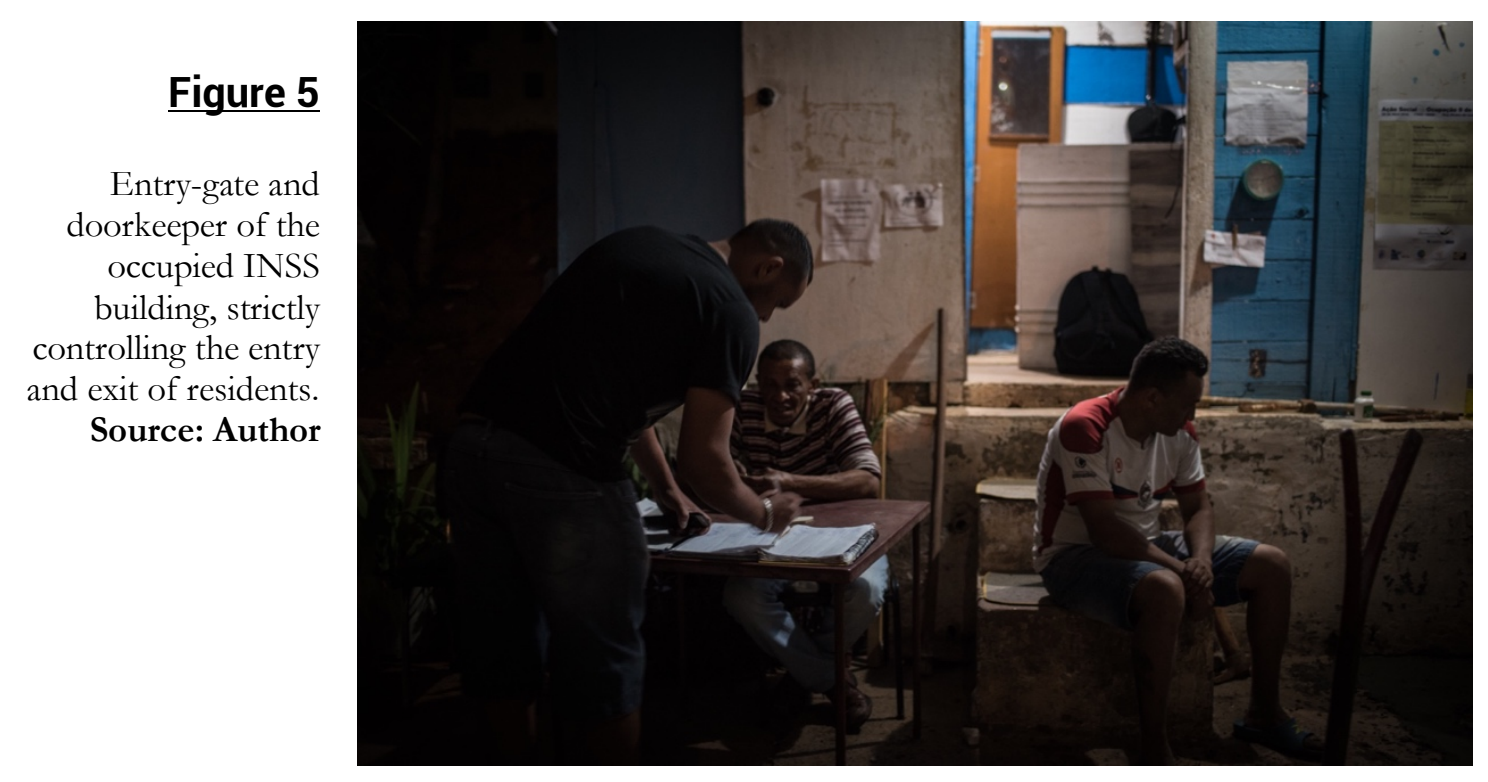

In March 2001, eight buildings were under negotiation between the respective owners, the occupation movements, and the public authorities. ${ }^{9}$ Liberated from rent, and aided by

\footnotetext{
${ }^{8}$ Folha de São Paulo, 25 November 2000

${ }^{9}$ Folha de São Paulo, 3 March 2001
} 
numerous educational and social activities, occupations engendered profound life improvements for numerous occupants. The libertarian inhabitation of the abandoned buildings-less restricted and controlled as rented tenements or social housing estatesimplied distinctive spatial qualities, allowing families to share and collectively maintain sanitation spaces and cooking, drying and washing rooms. The ability to open small shops, working spaces or other amenities in the buildings allowed families to make a living without having to make spatial investments elsewhere. The provisional encampments set up in the occupations radically impact everyday life and provided opportunities for numerous families. The transitional accommodation and social infrastructure found in occupations invoked a structural device for making ends meet and enabling people to crawl out of poverty, while acting as a highly educational environment that raises political awareness and mobilizes lowincome families to claim basic citizenship rights. Occupations offered an architectural and programmatic liberty (allowing spaces of cultural expression, working spaces, meeting rooms, social assistance, and many more), which is usually less present in more 'permanent' social housing estates. Be that as it may, many occupations continued to be largely precarious dwelling environments, afflicted by tenure insecurity, overcrowding, and insalubrious unventilated and unlit rooms.

After the UMM's turn towards short-term occupations, the MSTC was named the most 'radical' among the central squatter movements. Other movements that aligned with MSTC's direct action repertoire joined forces, and at a meeting in Ribeirão Pires in February 2004, MSTC, MMRC (a split-off from MMC) and MTSTRC established the Frente de Luta por Moradia (FLM), the Alliance of the Housing Struggle. The FLM brought together seven housing movements under the same banner. Other movements joined afterwards, comprising eleven movements represented by the FLM. As an 'umbrella' movement, the FLM maintains that occupations can be carried out simultaneously as political demonstrations, and as provisional housing solutions for their members. For FLM, the motives were always obvious: 'Miserable salaries, unemployment, real estate speculation ... the urbanized city expels the low-income workers from its entrails! ${ }^{10}$ Therefore, it does not suffice saying that one lives bad, it does not suffice provoking for revolt. . . It is necessary that the workers understand in all clarity why they live in poverty and with whom they should unite for fighting and liberating themselves from that misery!' (Del Rio, 2016, p. 168). Occupations, for FLM, became the principal means for synchronously making a more just city of more informed and independent citizens.

Ever since the organized building occupation of the Santos Dumont mansion in 1997, diverse housing movements have initiated numerous building occupations in the central area of São Paulo. They emerged as highly political and highly pragmatic instruments of social change, capitalizing by and large on the rich architectural availability of vacant buildings in the city's central area. It was in this context that both the MSTC and the FLM emerged as radical players in the centre's struggle for housing, advocating occupations as viable selfmade housing solutions. One of MSTC's most iconic occupations, occupied first in the late

\footnotetext{
10 Bolletim FLM, 2003.
} 
1990s, and occupied again by the same movement two decades later, will be discerned more in detail in the following section.

\section{INSS: An exemplary occupation}

The INSS building, located along São Paulo's central Nove de Julho Avenue was a notorious edifice ever since its construction in the 1940s. At present, it is one of the best known and most emblematic central building occupations, managed and maintained by the MSTC and the FLM. The building embodies a remarkable history. The following short building biography will offer insight in some of the particularities of building occupations in downtown São Paulo, and the specific role of vacant architecture in accommodating these squatting practices.

When the INSS building was inaugurated in 1943, in the middle of São Paulo's 'modernization boom', it was a hallmark of urban progress. The INSS building served as the headquarter of Brazil's National Social Welfare company. It was a fourteen-floor elegant modernist building of concrete and adobe, with luxurious marble staircases and a monumental portico facing the Nove de Julho Avenue. Multiple roof terraces and large balconies complemented six office floors, and eight floors accommodated spacious apartments for the Welfare Company's functionaries. Designed by Brazilian architect, Jayme Fonseca Rodrigues, the building was part of a vast wave of verticalization that took over the central area of São Paulo. The office building was abandoned - as were so many of these central skyscrapers - during the 1980s, when urban investment turned to 'new' central areas in the South-West of 'old' centre.

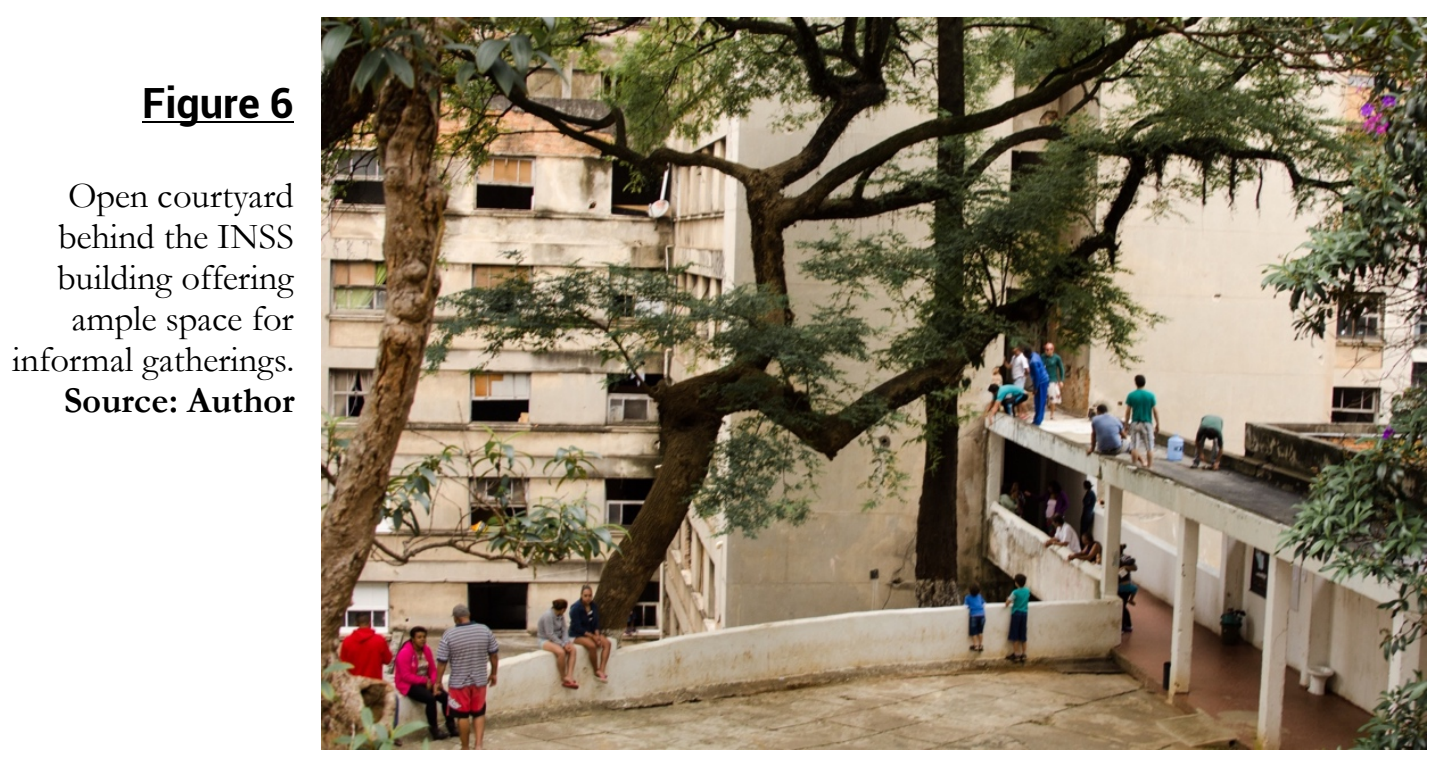

The Fórum dos Cortiços occupied the vacant edifice in 1997. The movement managed to occupy the building for seven years, and during that time, more than 150 families pieced together what Ward (2002) has called 'home-made-homes' between the columns and structural walls of the building, subdividing the former office floors and apartments as 
multifamily dwellings. From the outset of the occupation, the Fórum entered in negotiations with the municipality to enforce a refurbishment project for the building, demanding permanent housing solutions in the building for the occupying families. The INSS occupations was without doubt one of the most exemplary squats of the centre, standing out with its rigid internal organization, strong political articulation, and the formation of multiple movement coordinators who would later play fundamental roles in the extension of central homeless movements. At the same time, the remarkable architecture of the INSS building gave instant prestige to the occupation. Dwellings, in fact, merely had to minimally adapt and inhabit the forceful structure of the edifice which easily served its new program. The modernist icon of progress and elegance was easily turned over into an icon of popular resistance.

Due to the remarkable status of the building, the municipal social housing company of São Paulo (COHAB) aimed in 2003 to make it a pilot-project of inner-city social housing. Together with the technical and social assistance of the architecture cooperative Ambiente, and in close collaboration with the Fórum dos Cortiços, a 'retrofit' restauration project was drawn up. The occupation's families participated in numerous meetings, workshops and negotiations. By 2004, a plan for the reform project was concluded. In agreement with the municipality and the architects, the occupants peacefully left the building, assuming to return soon into permanent social apartments.

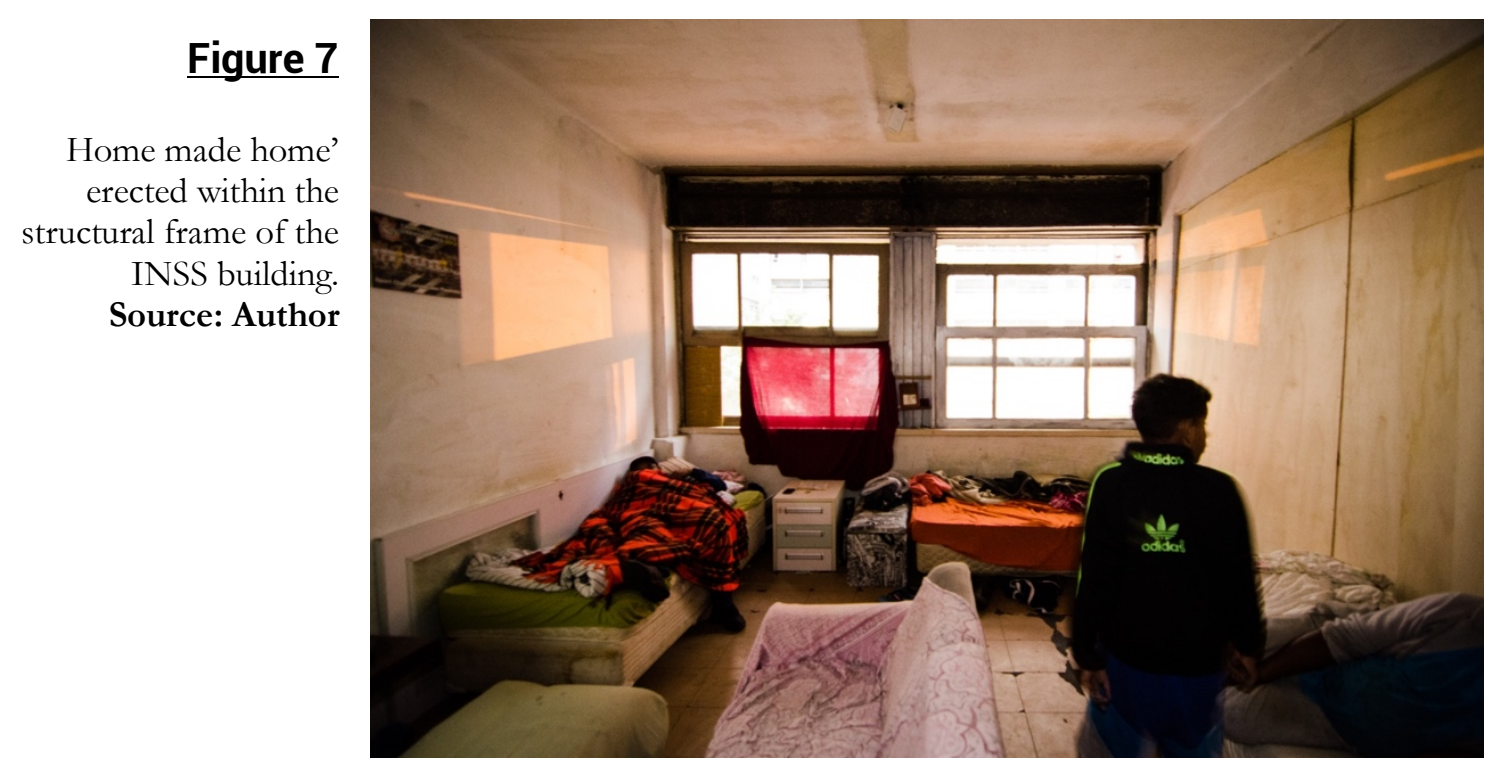

What was considered an unprecedented victory turned into a painful scandal. Restoration works never began. The building remained vacant. The re-vacated INSS building was sporadically used by individual squatters, and by cartel-affiliated dealers and users. In 2006, the edifice was burned by fire, and severe damage further jeopardized the promise of reform. Other occupations had in the meantime more success. Sanches (2015) illustrated how between 1990 and 2012, homeless movements compelled local authorities to repurpose or rebuilt not less than 37 central buildings to serve as social housing. As occupations 
meanwhile branched out in the centre's vacant building tissue, homeless movements finetuned their tactical repertoire and ideological discourse. Many movements evolved into highly politicized 'new protagonists' in the centre's political and spatial urban arena (Barbosa, 2014). By many observers, Holston's (2008) notion of 'insurgent citizenship' was frequently transposed from the city's self-constructed peripheral favelas to the reclaimed buildings in the centre. Earle (2017) defined central São Paulo's occupations as instances of 'transgressive citizenship,' emphasizing their inherent claims on dignified rights to the city. De Carli \& Frediani (2016) defined occupations as examples of 'insurgent regeneration', rendering such occupations as stepping stones towards inclusion, citizenship and social mobility. Despite all emphasis on insurgency and transgression, movements themselves maintain in fact a much humbler discourse, mostly defining their actions as mere 'repair' and 'recycling,' geared towards reform rather than revolt.

\section{Figure 8}

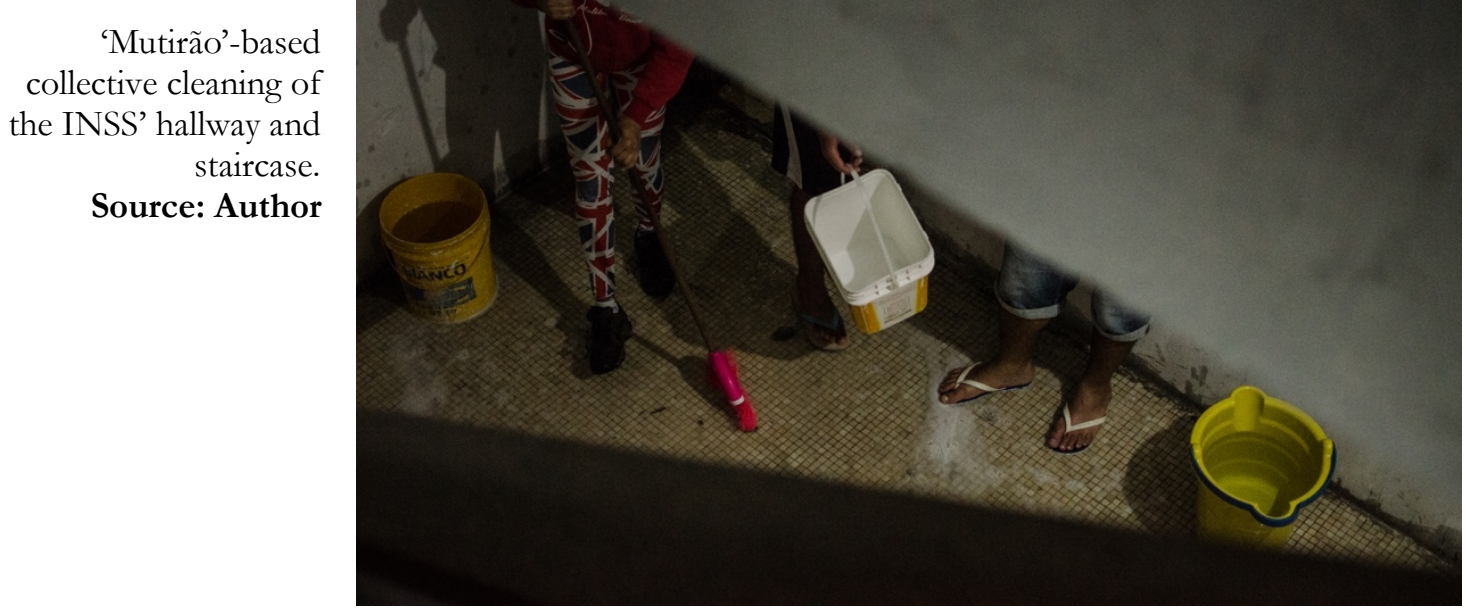

Two decades after the centre's first organised homeless occupation, multiple homeless movements, following different political lineages, adopting diversified tactics and maintaining divergent internal doctrines, had occupied hundreds of downtown vacant buildings. In addition, a vast array of squatters operated in the central city without organized movements or with less explicit political lineages. Some occupations became illustrative caseexamples. The notorious Hotel Cambridge, for instance, was occupied in 2012 by MSTC, which inhabited the building with 170 of the city's lowest income families. The erstwhile downtown hotel served as the scene and subject of the now famous 'Era Hotel Cambridge' movie, ${ }^{11}$ while hosting endless series of highly politicized gatherings and communal initiatives related to education, care, and production (Stevens, 2017). Also, the twenty-six floor Prestes Maia building became an epitome of popular resistance, recurrently occupied and evicted, but today again housing more than 500 families in the relicts of a concrete industrial complex.

11 The film 'Era Hotel Cambridge', by the well-known Brazilian producer Eliane Caffé was largely filmed inside the occupation, and many occupations play prime roles. The film was launched in 2017 and gained multiple prizes. See also Caffé (2017) 
As a genuine micro-cosmology, the derelict building is now replete of micro-adaptations that seek to readjust it for collective inhabitation and small-scale commerce.

The INSS building was meanwhile occupied at least another four times, but instantaneous evictions abruptly ended their persistence each time. In 2016, the Hotel Cambridge occupation (a mere 100 meters from the INSS building) was about to undergo the same process of 'de-occupation' to allow a promised retrofit project to start, similarly to the procedure followed in 2004 for the occupied INSS building. Consequently, MSTC (still led by former members of the Fórum dos Cortiços), occupied the building again on 30 September 2016, re-baptizing the building into 'Ocupação 9 de Julho,' named after the avenue it faces. Despite a confrontation with military police, the occupants managed to stay and the slow process of appropriation re-commenced. Self-construction started again, seeking to make the 75-years old building structure re-inhabitable again for a population left without other dwelling options.

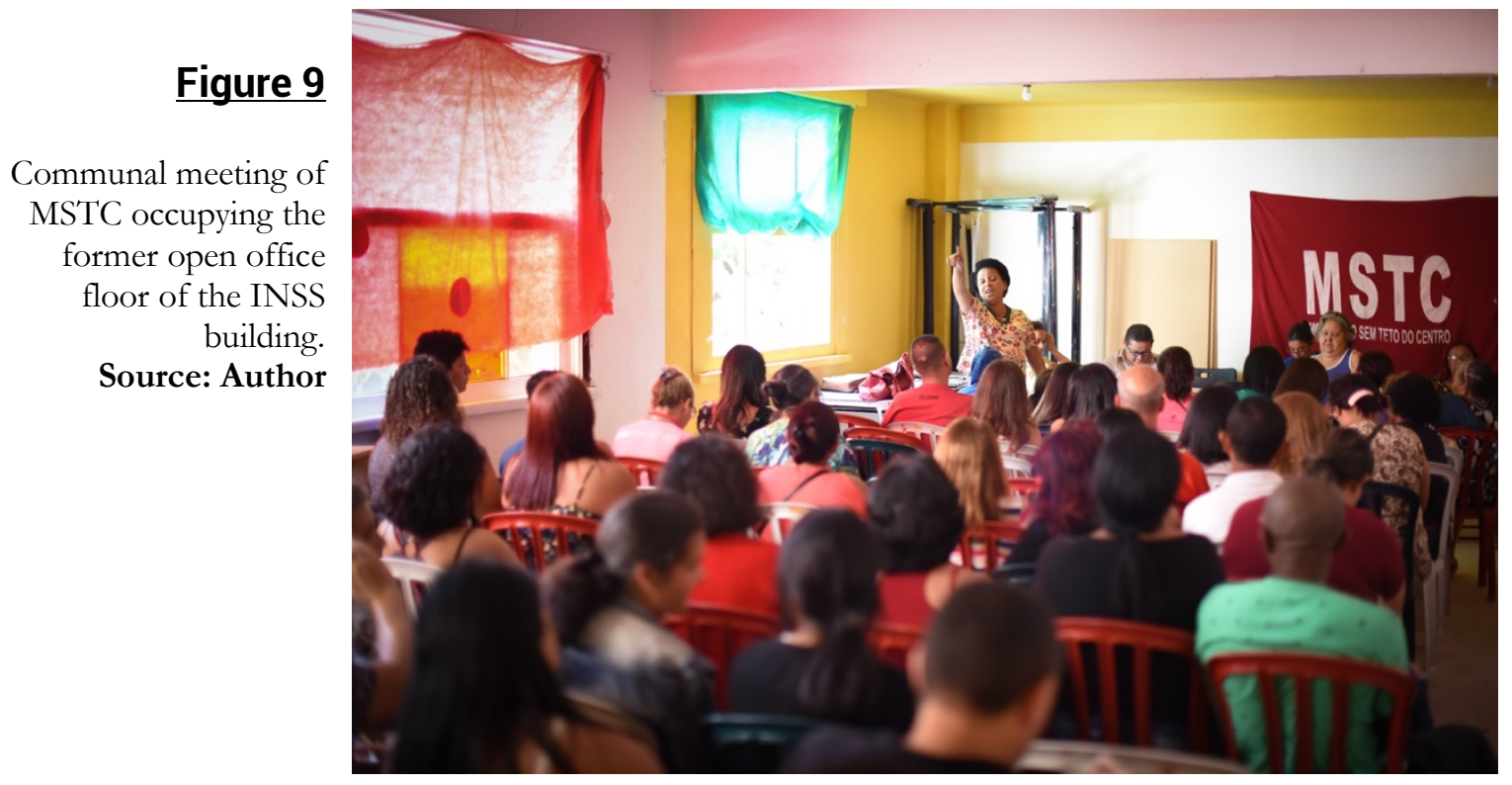

By 2018, the entire building's fourteen floors were occupied by 122 homeless families. Half of those were former residents of the Hotel Cambridge occupation. After installing basic technical provisions, such as water, electricity and sewage, individual dwellings were constructed using a combination of plywood panels, brickwork, and drywall. On the third floor, a large meeting room, classroom, wood atelier, office spaces, and two large collective kitchens were organized, allowing the building to become the movement's prime headquarter, twenty years after it had served the same function for the Fórum dos Cortiços. Large outdoor spaces were transformed into a soccer field, communal garden, and playground. Two decades after its first iconic occupation, it is now re-established as one of the most iconic central squats of São Paulo. It is exemplary, but not exceptional. Numerous other occupations are scattered in the central city's urban fabric, fomenting an alternative city hidden within the city. 


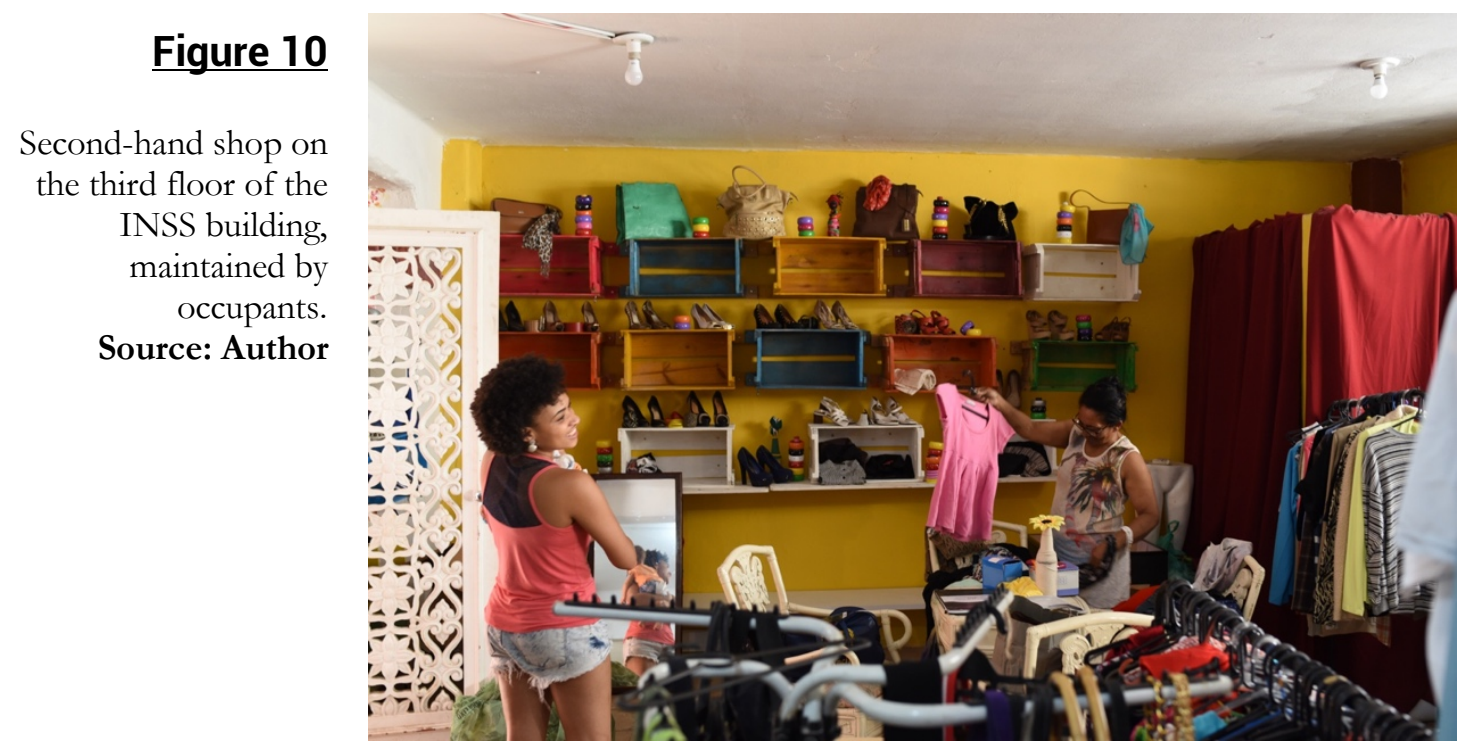

\section{Concluding remarks: From the right to the city to the right to the centre}

The overall history of central São Paulo's homeless movements, their direct struggle to overcome the city's appalling housing question, and the resulting collective self-construction of temporary solutions in occupied buildings illustrate a remarkable quest for tangible rights to inhabit the centre in a more affordable and dignified way. They provide viable alternatives to the cortiços or street-dwelling conditions upon which the working class usually have to rely upon if they want to reside downtown. Homeless occupations have come to embody a double-coded demonstration for rights to the city. On the one hand, occupations denounce the right to live in the centre by struggling for social housing projects and improvements of cortiços. This has resulted in multiple social housing projects in the central area, while directly influencing the 1988 constitution and subsequent municipal urban planning policies. On the other hand, homeless movements simultaneously 'demonstrate' the possibility to tackle the centre's housing issues by autonomously setting out piece together self-constructed 'rights to the city' in occupied buildings. Here, their spatial practices resonate with Lefebvre's (1968) theoretical notion of the right to the city, as the right to autonomously co-produce the city. In the central occupations of São Paulo such claims on the right to the city shifted from more general to very specific claims to the right to autonomously seize and develop vacant buildings in the very centre of the city. This implied an implicit claim to all the urban qualities and locational assets that the central city embodies. For MSTC and FLM, the urban poor should not only have the right to a roof above their head. They should, instead, have the right to dwell in decent buildings, close to urban services and infrastructure, amidst social, commercial and cultural amenities. Their claim on urban rights embodies a claim on the entire opportunity structure that the city has to offer, and the centre functions as the fundamental spatial arena to stake out such claims. If anything, the homeless occupations in central São Paulo, such as the remarkable INSS occupation, demonstrate the incredible opportunities held by the centre's vacanct architectural patrimony, and open possibilities for the literal construction of tangible rights to the city for its most poor and disadvantaged populations precisely there where it is probably most opportune. 
Closely bound up with the centre's historical propagation of cortiços, and catalyzed by the widespread abundance of vacant buildings, building occupations have emerged as a structural housing typology, that is, a recognizable architectural 'type' with multidimensional variations and appearances, in downtown São Paulo. Formerly obsolete buildings have become recycled into social and liberating infrastructures, providing thousands of families with a transitional shelter in the very centre of the city. As this historical genealogy aimed to illustrate, such occupation practices are deeply rooted in the historical DNA of the central city and its particular urban development. Its contemporary presence resonates with former cycles of urban abandonment of reclaim. As millions of low-income urbanites in São Paulo and elsewhere in Latin-America are currently facing renewed urban challenges, they simultaneously offer potential spaces of departure to imagine alternative urban futures where organized civil society is working towards more inclusive and socially just models of urban development.

\section{References}

Arantes, P. F. (2013). Direct action, housing production and people's power in São Paulo, Brazil. Lecture at KU Leuven, 5 may 2013. Seminar: The vicissitudes of design and participation in urban development.

Apoio, \& Celestino, W. (1998). Cortiços: uma Realidade que Ninguém Vê. São Paulo: Apoio, Associação de Auxílio Mútuo da Região Leste.

Barbosa, B. R. (2014). Protagonismo dos Movimentos de Moradia no Centro de São Paulo: Trajetória, Lutas e Influencias nas Políticas Habitacionais. (Dissertação de Mestrado), Universidade Federal do ABC.

Boff, L., \& Boff, C. (1986). Como Fazer Teologia da Libertação. Petropolis, Rio de Janeiro: Editora Vozes.

Brillembourg, A., \& Klumpner, H. (2012). Torre David. Informal Vertical Communities. Lars Muller Publishers.

Burdick, J. (1992). Rethinking the Study of Social Movements: The Case of Christian Base Communities in Urban Brazil. In A. Escobar \& S. E. Alvarez (Eds.), The Making of Social Movements in Latin America: Identity, Strategy and Democracy (pp. 171-184). Boulder, San Francisco, Oxford: Westview Press.

De Carli, B., \& Frediani, A. A. (2016). Insurgent Regeneration: Spatial practices of citizenship in the rehabilitation of inner-city São Paulo. GeoHumanities, 2(2), 331-353.

Del Rio, M. (2016). No Meio do Redemoinho: a Luta é Sempre. São Paulo: Editora Casa Flutuante.

Earle, L. (2009). Occupying the Illegal City. Urban Social Movements and Transgressive Citizenship in São Paulo. London School of Economics and Political Science.

Earle, L. (2017). Transgressive Citizenship and the Struggle for Social Justice. The Right to the City in São Paulo. London: Palgrave Macmillan.

Escobar, A., \& Alvarez, S. E. (1992). The Making of Social Movements in Latin America: Identity, Strategy and Democracy. Boulder, San Francisco, Oxford: Westview Press.

Fanon, F. (1961). Les Damnés de la Terre. Paris: François Maspero Editeur.

Fernandes, E. (2011). Implementing the urban reform agenda in Brazil. Possibilities, challenges, and lessons. Urban Forum, 22(3), 229-314.

Freire, P. (1968). A Pedagogia do Oprimido. Rio de Janeiro: Paz e Terra.

Gilbert, A. (1994). The Latin American City. London: the Latin American Bureau. 
Holston, J. (2008). Insurgent Citizenship. Disjunctions of Democracy and Modernity in Brazil. Princeton: Princeton University Press.

José, B. K. (2007). Políticas Culturais e Negócios Urbanos: A Instrumentalização da Cultura na Revitalização do Centro de São Paulo 1975-2000. São Paulo: Annablume.

Kohara, L. (2013). As contribuições dos movimentos de moradia do centro para as politicas habitacionais e para o desenvolvimento urbano do centro da cidade de São Paulo. (Pós-Doutorado), São Paulo.

Kowarick, L., \& Ant, C. (1989). One Hundred Years of Overcrowding. Slum Tenements in the City. In L. Kowarick (Ed.), Social Struggles and the City. The case of São Paulo. New York: Monthly Review Press.

Lefebvre, H. (1968). Le droit à la ville. Paris : Anthropos.

Levy, C. (2005). The Housing Movement in the City of São Paulo: Crisis and Revival. In M. Duquette, M. Galdino, C. Levy, B. Marques-Pereira, \& F. Raes (Eds.), Collective Action and Radicalism in Brazil: Women, Urban Housing, and Rural Movements (pp. 97-129). Toronto, Buffalo, London: University of Toronto Press.

Levy, C. (2010). Brazilian urban popular movements: The 1997 mobilization of the inner-city slum movement in São Paulo. Studies in Political Economy, 85(Spring), 35-68.

Maricato, E. (2011). O Impasse da Política Urbana no Brasil. São Paulo: Editora Vozes.

Neuhold, R. d. R. (2016). Movimentos Sociais e Políticas Públicas: Um Panorama das Lutas por Habitação Social na Área Central da Cidade de São Paulo. Dilemas: Revista de Estudos de Conflito e Controle Social, 9(1), 19-43.

Pasternack Tascher, S. (1995). Squatter settlements and slums in Brazil: Twenty years of research and policy. In B. C. Aldrich \& R. Sandhu (Eds.), Housing the urban poor: policy and practice in developing countries. London: Zed Books.

Rolnik, R. (1997). A Cidade e a Lei. Ligislação, Política urbana e Territórios na Cidade de São Paulo. São Paulo: Studio Nobel.

Sader, E. (2001). Quando Novos Personagens Entraram em Casa. Experiências, Falas, e Lutas dos Trabalhadores da Grande São Paulo, 1970/80 (4 ed.). Rio de Janeiro: Paz e Terra.

Sanches, D. (2015). Processo Participativo como Instrumento de Moradia Digna. Uma Avialiação dos Projetos da Área Central de São Paulo - 1990 a 2012. PPGAU Mackenzie, São Paulo.

Santos, M. (1996). São Paulo: A Growth Process Full of Contradictions. In A. Gilbert (Ed.), The Mega-City in Latin America (pp. 224-240). Tokyo, New York, Paris: United Nations University Press.

Secretaria Municipal do Planejamento. (1986). Cortiços em São Paulo: Frente e Verso. São Paulo: Municipio de São Paulo.

Stevens, J., De Meulder, B., \& Sanches, D. (2019). Cortiços. Interstitial Urbanization in Central São Paulo. In R. Rocco \& J. Van Ballegooien (Eds.) The Routledge Handbook on Informal Urbanization (pp. 248-258). New York, London: Routledge.

Zibechi, R. (2012). Territories in Resistance. A Cartograpby of Latin American Social Movements: AK Press. 